УДК 340.12

Олена Миколаӥвна Оверчук, аспірант юридичного факультету

Київського національного університету імені Тараса Шевченка

\title{
АКТУАЛЬНЕ ПИТАННЯ ТЕОРЕТИКО-ПРАВОВИХ ПІДХОДІВ ЩОДО РОЗУМІННЯ ПРАВОТВОРЧОСТІ
}

Постановка проблеми. В сучасних умовах становлення правової та незалежної держави реформується й чинне законодавство, здійснюється його гуманізація. Сформовано та стрімко розвиваються новітні галузі права, проте темпи розбудови правової держави є досить повільними, а постановка проблеми правової держави щодо практичної площини - не має ще належного теоретичного осмислення. Наразі проблематика правотворчості досліджується новим поколінням науковців, проте сучасна юридична наука не залишає простір для наукового осмислення щодо загального й універсального визначення правотворчості.

Аналіз останніх досліджень та публікацій. На сьогодні залишається актуальним питання щодо дослідження поняття правотворчості. Дана проблема має бути досліджена з різних підходів, а саме: філософсько-правовому, соціологічному та інструментально-правовому. Даний аспект розвиває сучасне праворозуміння, про що свідчать праці останнього періоду дослідження В. П. Казимирчука, В. М. Кудрявцева, С. С. Алексєєва, Д. А. Керімова, Ю. І. Гревцова та І. Ю. Козліхіна, К. К. Жоля, Н. М. Оніщенко, Ю. А. Тихомирова, О. І. Ющика, В. О. Зайчука.

Мета статті. Метою статті є дослідження історичних, теоретичних та правових основ правотворчості. Відтак доцільно, на нашу думку, буде дослідити правову природу правотворчості. Варто зазначити, що запропонований матеріал не ставить за мету історичне дослідження правотворчості - безперечно, складного та багатогранного явища, а зупиняється лише на його сутнісних, гносеологічних аспектах. Тому уявляється можливим розглянути пізнавальні засади доктринального розуміння правотворчості в розрізі існуючих у зарубіжній та вітчизняній юридичній літературі наукових підходів вчених, а також у контексті правотворчої діяльності держави.

Основні результати дослідження. В сучасних умовах становлення правової та незалежної держави проблематика правотворчості досліджується новим поколінням науковців.

На перший погляд питання про визначення правотворчості не є актуальним. Юридична література пропонує чисельну кількість спроб інтерпретувати це політико-правове явище на основі досить різноманітних методологічних принципів і прийомів. Разом з тим проблему навряд чи можна вважати вичерпаною.

Питання поняття правотворчості так само багатогранне, як і поняття права. Будь-яка спроба розгляду права з нових методологічних позицій, виявлення нових аспектів формування, виникнення та дії права неминуче веде до пошуку нового трактування поняття правотворчості. В останні роки багатопланова проблема правотворчості в різних іiі аспектах стала предметом багатьох науковотеоретичних досліджень.

Держава має творити право для людини та для їі блага. Держава існує для людини, для захисту загальновизнаних прав та свобод.

Основним джерелом Давньоруського права був правовий звичай, договірна практика, церковна правотворчість [12, с. 45-48]. Першим письмовим джерелом права на території сучасної України була Руська правда [24, с. 34-45].

Акцентуючи увагу на розвитку Давньоруської держави ранньофеодального періоду, слід зазначити дещо більшу роль церковної правотворчості, ніж істотно меншу рецепцію норм зарубіжного права. На відміну від заходу, де рецепція норм римського права становила майже основу всього середньовічного приватного права, рецепція норм візантійського права з боку Давньоруської держави відображала більш помірний характер [8, с. 120].

За часів феодальної роздробленості, правотворчість не приносить жодних нових тенденцій і є скоріше посиленням тих початків, які вже склалися в Стародавній Русі, перш за все, це стосується 
посилення ролі княжих актів як джерел права. У той же час посилення це має певну особливість. Більшість княжих актів в своєму змісті відтворювали вже існуючі правові звичаї та практику, які влада санкціонувала. Тим самим, зникаючи, як особлива форма, правовий звичай зберігався в князівських узаконеннях в якості правового джерела. В цьому плані витіснення звичаю відбувається більш повільно, ніж на Заході, й закон остаточно «перемагає» його лише в XVIII ст. [12, с. 126-128].

Судебники 1497 р., 1550 р. та 1555 р. дозволяють простежити становлення зазначених поглядів, і своєрідним підсумком цієї систематизації вважається Соборне уложення 1649 р., що є видатною пам'яткою права, в якому вперше зроблена спроба систематизувати норми за галузевою ознакою. Розробка й прийняття Соборного уложення 1649 р. дозволяє відзначити ще одну нову еволюційну лінію - початкове становлення поглядів про правотворчий процес. У даному аспекті слід погодитися з думкою В. О. Ключевського, що виділяють не лише умовні, а й самостійні стадії розробки й прийняття цього документа [10].

3 позицій законодавчої техніки XVIII ст. поширеними прийомами істотного прогресу залишалися: доповнення старої норми новим положенням, заміна окремих термінів і фраз в правовому тексті, угруповання норм за хронологічним принципом. Прийнятна диференціація норм за галузевим принципом була відсутня. Разом з тим протягом зазначеного періоду відбувається відносна стабілізація правотворчого процесу, подальше усвідомлення галузевого принципу систематизації, робиться хоча й невдала, спроба (Укладена комісія 1766 р.) зв'язати правотворчу діяльність 3 громадською думкою [9].

До середини XIX ст. завдання систематизації нормативного матеріалу були успішно вирішені, й прийнятий в 1832 р. Звід законів Російської Імперії не поступається західним формам права того часу щодо юридичної техніки свого виконання. XIX століття в еволюційному плані розвитку правотворчої функції є досить плідним. Вперше розробка нормативних актів будується на основі свого наукового обгрунтування, формуються чіткі уявлення про різні завдання інкорпорації та кодифікації, відбувається поділ приватного й публічного права [20], за предметним критерієм складаються основні галузі, на доктринальному рівні чітко усвідомлюється необхідність поділу матеріального й процесуального права [14, т. II].

Формування власної правової системи Українська Центральна Рада розпочала відразу після Жовтневого перевороту. 25 листопада 1917 р. Радою ухвалено Закон про правонаступництво, за яким усі закони Російської держави зберігали чинність на території України. Центральній Раді було дозволено ухвалювати нові закони й від імені Української Народної Республіки та скасовувати попередні. На той час Центральна Рада ухвалила кілька важливих законодавчих актів. Перший Універсал - звернення програмного характеру (10.06.1917), де висловлювалося прагнення до волі, до права самостійного впорядкування своїм життям, до створення шляхом рівного, прямого й таємного голосування Українських Установчих зборів, до національно-територіальної автономії в складі Росії. В документі йшлося про необхідність ліквідації приватної власності на землю. Другий Універсал (3.07.1917р.) став наслідком переговорів уряду Центральної Ради з представниками Тимчасового уряду.

Надалі еволюційний розвиток правотворчої функції фактично повністю було перервано революційними подіями. Формування основ нового права почалося з початком існування Української радянської держави як федеративної частини Російської Республіки з грудня 1917 року. На І-му Всеукраїнському з'їзді Рад 6 січня 1918 р. її проголосили Українською Радянською Соціалістичною Республікою (УРСР). Видання перших декретів Другого всеросійського з'їзду Рад, які сформували його принципи. Зокрема, Декрет про суд № 1 відміняв дію старих законів, якщо вони суперечили революційній правосвідомості [5, с. 12-18]. У перші роки радянської влади революційна правосвідомість стала головним джерелом права при відсутності нових писаних норм. Пріоритет революційної правосвідомості в якості джерела права грунтувався на пануванні в перші роки революції психологічної теорії права, яка вважала найважливішим аспектом правової реальності саме правосвідомість, а не норму й не правовідносини [1]. У 1917-1918 рр. приймаються нові декрети про суд, в кожному з яких, так чи інакше, інтерпретувалося поняття революційної правосвідомості. Так, в ст. 5 Декрету про суд № 1 (1917 р.) йшлося про «революційну совість» і «революційну правосвідомість» як про синоніми, в ст. 36 Декрету про суд № 2 (1918 р.) згадувалося вже «соціалістична правосвідомість», а в ст. 22 Декрету про суд № 3 (1918 р.) «соціалістична совість» $[4$, с. 239]. 
На початку 20-х рр. правознавці приділяли важливе значення, як провідної формі правотворчості, надавали й судовим рішенням. Це частково пояснювалося тим, що декрети цього періоду (19171920 pp.) були розрізнені й не приведені в систему [6, с.119]. На даному етапі «революційна правосвідомість» складала стереотип «революційної законності» взагалі, яка, в свою чергу, майже збігалася з поданням про «революційну доцільність». Лише до кінця періоду «воєнного комунізму» в правовій теорії відбулася певна диференціація цих категорій.

3 переходом до непу правосвідомість стала розглядатися в якості «провідного принципу правотворчості, покладеного в основу законодавства, що найбільш виразно виявляється в змісті прийнятих кодексів» [16, с.104]. Сама кодифікація розглядалася в зв'язку з цим тільки як етап в здійсненні революційної правосвідомості (або доцільність), як спосіб «кращого, в даних умовах, досягнення мети» [23, с.127].

Уже в 1919 році П. І. Стучка запропонував розпочати кодифікацію нового права. Головне місце повинна була зайняти Конституція. Далі йшло «соціальне право», що включає сімейне та право соціального забезпечення. Потім повинні були розташовуватися «майнові права». Завершувати збірник повинні були кодифіковані правила про працю, договірне право й міжнародне право. На думку автора, систематизовані таким чином норми складуть «обов'язкове для всіх право», тоді як всі подальші узаконення будуть представляти собою лише технічні інструкції [17]. Початок двадцятих років минулого століття стали періодом інтенсивної кодифікаційної роботи. Були прийняті й набрали чинності Цивільний, Кримінальний, Земельний, Цивільний процесуальний, Кримінально-процесуальний кодекси, Кодекс законів про працю, а так само розроблені проекти Господарського, Торгового, Промислового, Кооперативного, Адміністративного кодексів.

3 утворенням СРСР проводилися роботи в сфері союзного законодавства: були прийняті Основи судоустрою Союзу РСР і союзних республік, Основи кримінального законодавства Союзу РСР і союзних республік, Загальні засади землекористування і землеустрою, Повітряний, Митний кодекси та ряд інших важливих кодифікаційних актів. У 1928 р. з'явилося неофіційне «Систематичне зібрання діючих законів СРСР», яке складалося з шести томів [17, т. 16.].

Упродовж кількох років відбулася систематизація Кримінального (1960р.), Кримінально-процесуального (1969р.), Цивільно-процесуального (1963р.) кодексів УРСР, було ухвалено інші кодекси й нормативно-правові акти, які сприяли вдосконаленню правової системи.

Значну увагу щодо проблематики правотворчого процесу було приділено в працях вченого В. М. Горшенева [19, с. 67].

Соціалістична система права розглядала правотворчість крізь призму, що класифікує систему марксизму. Тема правотворчості активно розроблялася в 70-80-х. роках ХХ ст. завдяки роботі вчених С. С. Алексєєва, А. В. Міцкевича, А. С. Піголкіна, А. Нашиц та багатьох інших. За економічною теорією К. Маркса, правотворчість - це форма державного керівництва суспільством, що завершує процес формування права та відображає соціальні фактори цього процесу у вигляді перетворення волі пануючого класу, які наділені державно-владними повноваженнями, у загальнообов’язкові правила поведінки - правові норми [11, с. 19-20].

3 початком 90-х років XX століття відбувається процес інтенсифікації науки, осмислення правотворчості та відповідно формуються і розвиваються нові підходи щодо ії розуміння. Так, на думку вченого В. В. Іванова, поняття «правотворчість» охоплює встановлення правових норм. За своїм фактичним змістом правотворчість - це система організаційно-процесуальних дій суб'єктів права (державних і недержавних установ), що спрямована на встановлення правових норм. До способів правотворчої діяльності (які можна назвати ії видами), на думку вченого, слід віднести й законотворчість, підзаконну, прецедентну та договірну правотворчість [3, с. 85-97].

У працях українських вчених, правотворчість часто розглядається як один із етапів правоутворення (в юридичній літературі також зустрічається як «правотворення»). Такої думки дотримуються вчені О. Ф. Скакун, В. В. Копейчиков, В. С. Ковальський та І. П. Козінцев. Так, вчений О. Ф. Скакун обгрунтовує свою позицію тим, що правоутворенням $€$ всі форми та засоби виникнення, розвитку та зміни права, у тому числі й правотворчість. А головною відмінністю правотворчості від правоутворення $є$ те, що творчість права здійснюється державними органами або з їх санкції, дозволу [15, с. 239].

Вчений В. М. Карташов розглядає правотворчість як один із видів юридичної діяльності, що визначається залежно від характеру, способу перетворення суспільних відносин (поряд із правозастосовною, розпорядчою та інтерпретаційною діяльностями) [18, с. 23$]$. 
На думку Т. О. Дідича, це $є$ різновекторні дискусійні підходи до розуміння феномену правотворення. При цьому автор зазначає, що творення права $є$ особливий різновид юридичної практичної діяльності, який має творчий інтелектуальний характер та пов'язаний з розробкою, обговоренням, прийняттям та введенням в дію правових норм у вигляді форм (джерел) права, що обумовлений рівнем суспільного розвитку та забезпечує пропорційну залежність між потребами суспільства та адекватним якісним рівнем законодавчої бази [2, с. 91-94].

Акцентуємо увагу на думку вчених щодо правотворчості, за твердженням О. I. Ющика, згідно з яким трактується «вироблення законодавства в процесі державного управління суспільством, як особливого виду соціальної діяльності, а саме - юридичну діяльність, практичне здійснення якої відбувається як юридичний процес, що є іманентним способом державного управління та іменується законодавчим процесом» $[19$, с. 67$]$.

O. I. Ющик зазначає, що правотворчість і нормотворчість - це сфери, що певною мірою збігаються, однак не $є$ абсолютно тотожними. Якщо правотворчість означає творення права, то нормотворчість слід розуміти як творення норм. Оскільки в суспільстві існують різні норми (технічні, санітарно-гігієнічні, прагматичні тощо), а соціальні норми, до яких належать і юридичні, становлять лише частину з них, то це означає, що нормотворчість є більш загальне поняття, ніж правотворчість, виступає як родове поняття щодо творення соціальних норм, лише одним із різновидів якого $є$ правова нормотворчість, поряд із релігійною, мовною, етичною.

С. С. Цись зазначає, що виключна роль держави як суб'єкта правотворчості характерна для тоталітарних і авторитарних держав переважно соціалістичного спрямування із домінуючою державною формою власності [22, с. 69-72].

Натомість для держав із демократичним режимом таке уявлення про правотворчість не відповідає дійсності, адже теорія демократії передбачає серед іншого забезпечення рівної участі громадян в управлінні державними й суспільними справами. Дане обгрунтування міститься в працях ідеологів неолібералізму (Фридрих Август фон Хайек (нім. Friedrich August von Hayek) та Джон Ролз (англ. John Bordley Rawls) [21]; [13].

Дійсно, в демократичній державі створюються механізми для залучення інститутів громадянського суспільства до правотворчості, правотворчого процесу. Зокрема, робочі групи з розробки проектів нормативно-правових актів включають не лише державних службовців, а й представників неурядових громадських організацій, незалежних експертів, профспілок та інших.

Досліджуючи питання правотворчості, не слід протиставити роль держави в формуванні права «силам суспільства», оскільки це не наближає до пізнання права та правотворчості, а лише створює «ілюзію» такого пізнання. Ця «ілюзія», на думку вченого О. В. Міцкевича, полягає у визнанні деякого постулату «справжнього права», що нібито існує незалежно від держави у звичаї як продукті колективної свідомості. Насправді жодне правило не набуває характеру правової норми, доки воно не санкціоноване у формі закону, надання значення прецедента судовому рішенню, визнання й формулювання судом або законом звичаю. Вчений підсумовує, що силою, яка створює право, завжди виявляється держава, проте не «сама собою», а виражаючи інтереси й волю певної частини суспільства. Правила, що не встановлені й не санкціоновані державою, тобто такі, що виникли поза волею держави, належать не до права, а до інших видів соціальних норм [7, с. 273].

Дотримуємось думки, що правотворчість розглядається у традиційному значенні державної правової нормотворчості, що не виключає можливості дослідження вказаного предмета та бачення інших точок зору. На нашу думку, вивчення державної правової нормотворчості $є$ найбільш необхідним для задоволення практичних потреб державного управління виходячи з права.

Висновки. Як висновок, доводимо, що правотворчість має обгрунтоване світосприйняття з теоретико-правового простору щодо досягнення єдиного розуміння поняття терміна «правотворчість». Дослідивши проблематику розуміння правотворчості з позиції вчених-правознавців, позитивістський та природно-правовий підходи до правотворчості, iї співвідношення з іншими суміжними категоріями, виявляється можливим окреслити універсальну авторську дефініцію, яка б достатньо повно й суттєво відображала зміст правотворчості та підходила для характеристики цього поняття в різних правових системах і державних режимах.

Отже, правотворчість - це стадія правотворення, яка полягає в підготовці, внесенні змін та прийнятті нормативно-правових актів. 


\section{Список використаних джерел}

1. Бабенко В. Н. Судебная система России: история и современность. - М., 2007.

2. Дідич Т. О. Розуміння, творення і реалізація права: діалектика взаємозв'язку // Альманах права. - 2011. Вип. 2. - С. 91-94.

3. Иванов В. В. К вопросу о теории нормативного договора // Журнал российского права. $-2000 .-$ № 7. - C. 85-97.

4. Калинин А. Ю. Правообразование с позиций структурно-функционального подхода. - М., 2011. - С.2 39.

5. Кожевников М. В. История советского суда. 1917-1947 гг. - М., 1948. -С. 12-18.

6. Марченко М. Н. Источники права. - М., 2005. - С. 119.

7. Мицкевич А. В. Правотворчество в СССР / Под ред. А. В. Мицкевича. - М. : Юридическая литература, 1974. C. 273.

8. Оспенников Ю. В. Государство и право Северо-западной Руси в XII-XV веках : дисс. ... докт. юрид. наук. Самара, 2010.

9. Пайпс Р. Истоки гражданских прав в России - год 1785. - М., 2010.

10. Псковская судная грамота. Новый перевод, комментарий Л. В. Черепнипа и И. Я. Яковлева // Исторические записки. Т. VI. - М., 1940.

11. Плавич С. В. Теоретико-методологічні засади правотворчості : дис. ... канд. юрид. наук : $12.00 .01 /$ Плавич Сергій Володимирович; Одес. нац. ун-т ім. І. І. Мечникова. - К., 2009. - С. 19-20.

12. Радин И. М. История русского права. - СПб., 1910.- С. 45-48.

13. Ролз Дж. Идеи блага и приоритет права // Современный либерализм: Джон Ролз, Рональд Дворкин, Исайя Берлин, Уилл Кимлика, Майкл Дж. Сэндел, Джереми Уолдрон, Чарльз Тейлор / Пер. с англ. Л. Б. Макеевой. М. : Прогресс-Традиция: Дом интеллектуальной книги, 1998.

14. Сахаров А. Н. История России / Под ред. А. Н. Сахарова.- М., 2012. -Т. 2.

15. Скакун О. Ф. Теорія держави і права : підруч. / О. Ф. Скакун ; пер. 3 рос. - Х. : Консум, 2001. - С. 293.

16. Стучка П. И. Революционная роль советского права. - М., 1934. - С.104.

17. Стучка П. Учение о государстве и Конституции РСФСР. - М., 1920.

18. Систематическое собрание действующих законов СССР. Т. 1-6. - М., 1928.

19. Теория юридического процесса / Под общ. ред. В. М. Горшенева. - Х. : Изд-во «Вища школа», 1985. - С. 67.

20. Теремцова Н. В. Правове регулювання бюджетних відносин: теоретико-правовий аспект // Матер.VI-их наук. читань, присвячених пам’яті акад. В. В. Копєйчикова (17.11.2016) / Редкол.: А. М. Завальний, Н. В. Лазнюк, Д. О. Тихомиров. - К. : НАВС, 2016. -170 с. - С. 134-136 [Електронний ресурс]. - Режим доступу : http://www. naiau.kiev.ua

21. Хайек $\Phi$. Право, законодательство и свобода: современное понимание либеральных принципов справедливости и политики. - М. : ИРИСЭН, 2006. - 644 с.

22. Ц Цись С. С. Доктринальні засади правотворчості: проблеми наукового розуміння // Часопис Київського університету права. Вип.1. - К. : Ін-т держави і права ім. В. М. Корецького НАН України, 2015. - С. 69-72.

23. Чеченин В. Г. История отечественного государства / Под ред. проф. В. Г. Чеченина. - М., 2003. - С.127.

24. Черниловский 3. М. Русская правда в свете других славянских судебников // Древняя Русь: проблемы права и правовой идеологии. - М., 1984. - С. 34-45.

Оверчук О. М. Актуальне питання щодо теоретико-правових підходів розуміння правотворчості

У статті автором проведено узагальнення поглядів вчених на проблему розуміння поняття правотворчості. Проведено історичний аналіз розвитку даного поняття. Узагальнено та охарактеризовано поняття правотворчості щодо поняття термінів: «законотворчість», «правотворчий процес», «законотворчий процес», «нормотворчість».

Ключові слова: правотворчість, правотворчий процес, законотворчість, нормотворчість, законотворчий процес.

Overchuk O. M. The actual issue about teoretical and legal approaches to understanding of law-making.

In this article the author conducted synthesis the views of scientists on the problem of understanding the local lawmaking. A historical analysis of the development of this concept was conducted. Summarized and described definitions of law-making according to definitions: rulemaking, law-making process, rulemaking process, norm-making.

Key words: law-making, rulemaking, law-making process, rulemaking process, norm-making.

DOI: 10.33.66.3/2524-017X-2019-10-208-212 